\title{
DAMPAK SISTIM PENENTUAN KOSA KATA INDEKS PADA KARYA MONOGRAF TERHADAP TEMU BALIK INFORMASI PEMUSTAKA DI DINAS PERPUSTAKAAN DAN ARSIP KOTA JAMBI
}

\author{
Khatimah Harys \\ Imaharys80@gmail.com
}

PERPUSTAKAAN SMK NEGERI 4 KOTA JAMBI

\begin{abstract}
This writing aims to express about the subject analyse system that be done by librarian who has choosed the vocabulary to represent a document. This system analyse is very important because it will impact to information retrieval system. The librarian must analyse a document not only its but also its content, so that he will choose some good vocabularies. The system that had been done by the librarians of Dinas Perpustakaan dan Arsip Daerah Kota Jambi where they focused the topic of document, the uncontrolled vocobulary (bahasa alami) was not be translated in to controlled vocabulary (bahasa indeks), they didn't think the users who use library. The weakness factors are based on ; the librarian do not understand the foreign language, they can not be indexing, they do not understand the subject analyse process. This condition will affect on the unsatisfaction of users where they will not get a document that be needed, it is not effectiveness in searching, and it is more hingher acquirement than precision.
\end{abstract}

Key Word: Indeks, temu balik informasi, perpustakaan.

\section{A. Latar Belakang Masalah}

Indeks merupakan salah satu media yang digunakan untuk menemukan kembali informasi baik berupa karya monograf, terbitan berseri maupun karyakarya lain di perpustakaan, hal ini dimaksudkan agar proses temu balik informasi dapat dilakukan oleh pemustaka seara efektif dan efisien.

Menurut Evan bahwa indeks merupakan sarana yang lazim digunakan oleh pemustaka dalam proses menemukan informasi di perpustakaan jika dibandingkan dengan kepengarangan (author) maupun judul. ${ }^{1}$ Pemanfaatan indeks subjek sebagai media temu balik informasi dinilai oleh evan sangat efektif, ini terbukti dengan adanya berbagai teknologi informasi yang menyediakan menu keyword untuk penelusuran melalui dindeks subjek.

\footnotetext{
1 Andrei Z. Broder dkk, 2000. Identifying and filtering near-duplicate documents. In CPM
} '00,pages 1-10. 
Salah satu bentuk kegiatan indeks adalah pengindeksan. Pengindeksan merupakan salah satu bentuk kegiatan kepustakawanan (librarianship) yang harus dilakukan oleh para pustakawan khususnya pada pustakawan tingkat ahli di lingkungan pusat dokumentasi dan informasi (pusdokinfo). Tujuan dilakukan pengindeksan adalah untuk memberikan kemudahan bagi pemustaka (user) dalam proses temu balik (retrive) informasi.

Evan menyebutkan bahwa pengindeksan pada karya monograf sesungguhnya lebih mudah dilakukan jika sesuai dengan proses atau langkah-langkah pengindeksan yang telah diatur bersama pada pustakawan. ${ }^{2}$

Indexing is the process identifying information in a knowledge record text or nontext) an organizing the pointers so that information in to searchable file. ${ }^{3}$ Pengideksan adalah proses identifikasi informasi dalam sebuah catatan pengetahuan baik teks maupun non teks dan pengorganisasian nilai-nilai informasi untuk pencarian file.

Kegiatan pengindeksan yang dilakukan oleh para pustakawan sesungguhnya bukan merupakan perkara mudah karena selain dituntut untuk memahami isi dokumen, para pustakawan dituntut untuk memahami untuk memilih istilahistilah yang dapat mewakili dokumen, pengetahuan bahasa asing dan pemahaman terhadap pemustaka yang menggunakan perpustakaan untuk mengakses informasi. di lingkungan Dinas Perpustakaan dan Arsip Daerah Kota Jambi, pemanfaatan katalog subjek dan OPAC sebagai media temu balik informasi oleh pemustaka seringkali dihadapkan dengan munculnya masalah baik dari perolehan maupun ketetapan dalam penelusuran informasi padahal media-media temu balik informasi telah disediakan oleh pihak perpustakaan.

Tulisan ini menggambarkan bagaimana sistim pengindeksan subjek yang dilakukan oleh para pustakawan di lingkungan Dinas perpustakaan dan arsip Kota Jambi dan dampaknya terhadap sistim temu balik informasi.

${ }^{2}$ Edward Evans, Margaret Zarnosky Saponaro, 1995. Developing Library and Information Center Collections (Library Science Text Series) 3rd Edition, (Amazone, Libraries Unlimited : 1995), hlm. 428

3 Robert R. Korfhage. Publication of Korfhage's Information Storage and Retrieval with emphasis on visualization and multi-reference point systems. (Cranfield Collection of Aeronautics, Cranfield, England :1997). hlm. 97 


\section{B. Pengertian dan Konsep Kosa Kata Indeks dan Sistim Balik Informasi}

\section{Pengertian Indeks dan Pengindeksan}

Indeks berasal dari bahasa Inggris indicate berarti menunjukkan. Kata indicate ini berasal dari bahasa Latin indicare yang berarti menunjukkan/ to show. Menurut Lasa Hs dalam bukunya Kamus Kepustakawanan Indonesia indeks adalah petunjuk yang berupa huruf, angka maupun tanda lain untuk memberikan pengarahan kepada pencari informasi bahwa informasi yang lebih lengkap maupun informasi terkait dapat ditemukan pada sumber yang ditunjuk. ${ }^{1}$

Kosa kata indeks adalah kosa kata yang yang terdiri dari satu atau lebih kata yang diambil dari dokumen (monograf atau terbitan berseri). Kosa kata indeks seringkali disebut sebagai bahasa indeks (controlled vocabulary) yakni sekelompk istilah terbatas yang harus digunakan untuk mewakili subyke dokumen dalam suatu sistim temu balik informasi. ${ }^{2}$

Pengindeksan merupakan kegiatan pendeskripsian isi dokumen dengan memilih istilah yang paling tepat sehingga mewakili isi dokumen. Pengindeksan subjek merupakan bagian dari proses pengolahan dokumen/ bahan pustaka di perpustakaan. pengindeksan ini dilakukan dengan tujuan untuk membuat wakil dokumen sehingga memungkinkan ditemukannya dokumen yang relevan dengan suatu permintaan. ${ }^{3}$

Adapun tujuan Penyusunan Indeks adalah; efisiensi dan efektivitas dalam penelusuran informasi; memberikan informasi yang lebih rinci; memanfaatkan sumber informasi secara optimal; dan menganalisa, merinci, dan meringkas isi naskah menjadi unit-unit yang lebih kecil. Sedangkan fungsinya adalah alat penunjuk informasi ; alat penelusur informasi; dan alat penghubung antar subjek atau antar literatur.

\section{Pengertian Sistim Temu balik Informasi}

Lancaster mendefinisikan temu kembali informasi sebagai suatu proses pencarian dokumen dengan menggunakan istilah luas untuk

\footnotetext{
${ }^{1}$ Lasa HS. Jenis-Jenis Layanan Informasi Perpustakaan : sirkulasi dan Referensi. (Jakarta: Universitas : Gajahmada Press, 2006) hlm. 110

${ }^{3}$ Lancaster. Information Retrieval.... hlm. 196
} 
mengidentifikasi dokumen yang berhubungan dengan subjek tertentu". ${ }^{4}$ Sedangkan menurut Gerald Kowalski "sistem temu balik informasi adalah suatu sistem yang mampu melakukan penyimpanan, pencarian, dan pemeliharaan informasi. Informasi dalam konteks ini dapat terdiri dari teks (termasuk data numerik dan tanggal), gambar, audio, video, dan objek multimedia lainnya". 5

Sistem temu balik informasi merupakan sistem yang mampu melakukan pencarian informasi pada kumpulan dokumen, pencarian dokumen itu sendiri, pencarian metadata untuk dokumen tersebut, atau pencarian teks, suara, gambar, atau data dalam basis data dan pengambilan dokumen yang relevan dari sebuah koleksi dokumen sesuai dengan query pengguna sistem. Input dari suatu sistem temu balik informasi adalah query dari pengguna dan koleksi dokumen atau artikel, dan output-nya adalah dokumen atau artikel yang dianggap relevan oleh sistem. Sistem temu balik informasi ini digunakan untuk mengurangi informasi yang terlalu banyak sehingga sulit untuk dikelola. Tujuan dari sistem temu balik informasi adalah memenuhi kebutuhan informasi pengguna dengan me-retrieve semua dokumen yang mungkin relevan, pada waktu yang sama me-retrieve sedikit mungkin dokumen yang tak relevan.

\section{Efektifitas Temu Balik Informasi}

Efektifitas lebih merujuk pada berdaya hasil, tidak menggunakan banyak waktu, materi, tenaga dan fikiran dalam melakukan suatu kegiatan. Efektifitas bisa tercapai apa dilakukann memiliki pengetahuan, pengalaman, fasilitas pendukung dan adanya komunikasi dengan pihak lain untuk mendapatkan informasi mengenai metode atau sistim yang tepat terkait dengan aktifitas fisik.

Kamus bahasa Indonesia memaknai efektifitas sebagai suatu yang memiliki pengaruh atau akibat dari usaha atau akibat yang ditimbulkan, manjur, membawa hasil dan merupakan keberhasilan dari suatu usaha atau

\footnotetext{
${ }^{4}$ Kowalski, Gerald J. Information Retrieval Systems : Theory and Implementation. (USA: Springer, 2007). hlm. 2

${ }_{5}^{5}$ Kowalski, Gerald J. Information Retrieval.... hlm. 4
} 
tindakan, dalam hal ini efektivitas dapat dilihat dari tercapai tidaknya tujuan instruksional khusus yang telah dicanangkan. ${ }^{6}$

Wojtczak mendefisikan effectiveness in the context of medial education:

Effectiveness: A measure of the extent to which a specific intervention, procedure, regimen, or service, when deployed in the field in routine circumstances, does what it is intended to do for a specified population. ${ }^{7}$

Menurut Hasugian bahwa perolehan (recall) berhubungan dengan kemampuan sistem untuk memanggil dokumen yang relevan. Sedangkan ketepatan (precision) berkaitan dengan kemampuan sistem untuk tidak memanggil dokumen yang tidak relevan". 8 Rumus untuk menghitung nilai perolehan (recall) dan ketepatan (precision) adalah sebagai berikut :

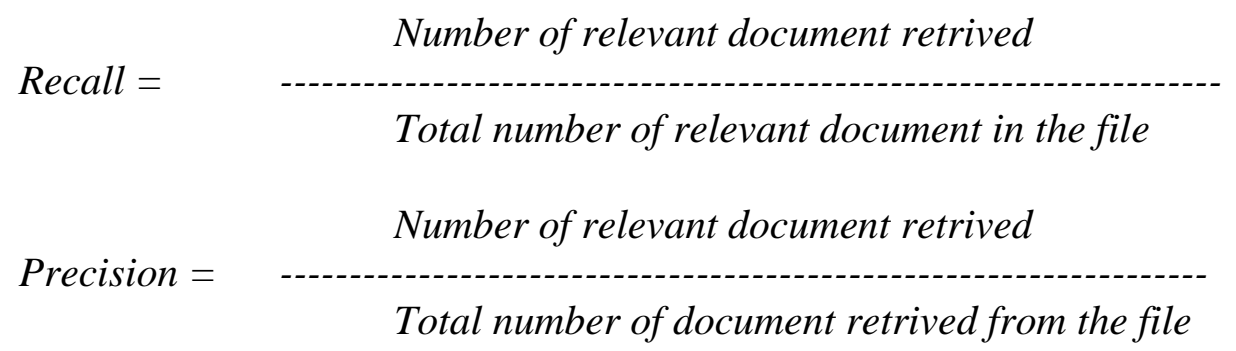

Rumus-rumus tersebut dapat diterjemahkan sebagai berikut :

$$
\begin{aligned}
& \text { Jumlah Dokumen yang Terambil } \\
& \text { Recall }(\text { Perolehan })=\text { Jumlah Dokumen Relevan yang Ada dalam Database }
\end{aligned}
$$

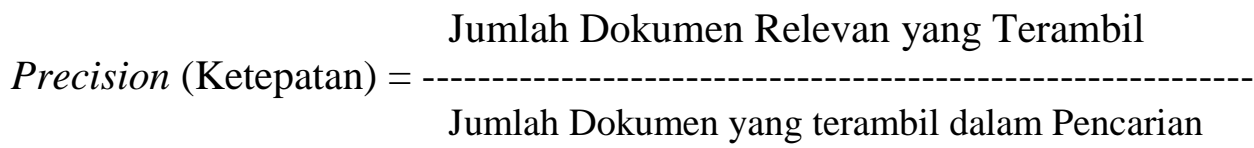

Menurut pendapat Rowley yang dikutip oleh menyatakan bahwa "suatu sistem temu kembali informasi dinyatakan efektif apabila hasil

\footnotetext{
${ }^{6}$ Anonim. Kamus Besar Bahasa Indonesia, (Jakarta: P dan K, 1994), hlm. 178

${ }^{7}$ Wojtczak, A., 2002, Glossary of Medical Education Terms, http://www.iime.org/glossary.htm, December, 2000, Revised February 2002, accessed 2 April 2016,

${ }^{8}$ Irma U. Aditirto. Kebijaksanaan Pengindeksan. Bahan Mata Kuliah Kosa Kata Indeks, Jurusan Ilmu Perpustakaan Fakultas Sastra Universitas Indonesia, 1997. hlm. 1
} 
penelusuran mampu menunjukkan ketepatan (precision) yang tinggi sekalipun perolehannya rendah". 9

Dengan demikian bahwa, proses temu balik informasi merupakan proses pencarian informasi yang dibutuhkan dengan harapan bahwa informasi yang diinginkan lebih tinggi ketepatan daripada perolehan.

\section{Kebijakan Pengindeksan}

Proses pengindeksan yang dilakukan oleh pustakawan atau pengindeks di lingkungan perpustakaan, dokumentasi dan informasi merupakan kegiatankegiatan yang membutuhkan kemampuan intelektual. Pustakawan dituntut untuk melaksanakan tugas kepustakawanan ini secara profesional agar menghasilkan indeks yang baik. Indeks yang baik tentunya akan memberikan efek terhadap kepuasan pemustaka dalam proses temu balik informasi. Menurut Zulfikar Zen bahwa kegiatan pengideksan yang dilakukan oleh pustakawan sejatinya memiliki pengetahuan yang memadai mengenai istilah-istilah subyek dalam berbagai ilmu pengetahuan. ${ }^{10}$ Selain itu, perkembangan ilmu pengetahuan dan teknologi juga menjadi tantangan bagi pustakawan dalam menjalankan tugas profesinya dalam melakukan pengindeksan.

\section{1) Pengindeksan Konsep (Assigned indexing atau concept indexing)}

Pengindeks mempelajari isi dokumen untuk mengidentifikasi ide-ide atau konsep-konsep penting yang dibahas dalam dokumen. Kemudian ia menggunakan bahasa indeks (seperti bagan klasifikasi atau daftar tajuk subyek) untuk menetapkan notasi atau tajuk subyek yang dapat mewakili konsep-konsep tsb.

Dalam assigned indexing atau concept indexing pengindeks tidak sekedar mengambil kata-kata yang ditemukannya dalam dokumen, tetapi harus mengenali konsep-konsep yang berada di belakang kata-kata tsb. Dengan demikian pemakai atau penelusur sistem temu balik informasi dapat menemukan kembali (retrieve) semua dokumen tentang konsep tertentu, meskipun istilah yang ia gunakan untuk

\footnotetext{
${ }^{9}$ Hasugian, Jonner. Dasar-Dasar Ilmu Perpustakaan dan Informasi. (Medan: USU Press, 2003) hlm. 5

${ }_{10}$ Zulfikar Zen, 2013. Pengantar Ilmu Perpustakaan. Makalah disampaikan pada Diklat: Manajemen Perpustakaan yang diselenggarakan oleh BADAN LITBANG DAN DIKLATDEPARTEMEN AGAMA RIJakarta, 10 - 16 April 2008. hlm. 4
} 
konsep tsb. Berbeda dari istilah yang digunakan penyusun dokumen atau istilah yang digunakan dalam sistem temu kembali untuk konsep tersebut.

Dalam penentuan subyek buku atau bahan pustaka lainnya diperlukan analisis subyek. Kegiatan analisis subyek memerlukan kemampuan yang memadai, sebab di sinilah pengindeks dituntut kemampuannya untuk menentukan subyek apa yang dikandung dalam bahan pustaka yang diolah. Ada tiga hal yang mendasar perlu dikenali pengindeks dalam menganalisis subyek yakni :

\section{a. Jenis konsep}

Dalam satu bahan pustaka dapat dibedakan tiga jenis konsep yaitu:

1) Disiplin ilmu, yaitu istilah yang digunakan untuk satu bidang atau cabang ilmu pengetahuan. Disiplin ilmu dapat dibedakan menjadi 2 kategori:

a) Disiplin fundamental, yang meliputi bagian-bagian utama ilmu pengetahuan. Oleh para ahli disiplin fundamental dikelompokkan menjadi tiga yakni ilmu-ilmu sosial, ilmu-ilmu pengetahuan alam, dan ilmu-ilmu kemanusiaan.

b) Sub disiplin, merupakan bidang spesial dalam satu disiplin fundamental. Misalnya dalam disiplin ilmu fundamental alam, sub disiplinnya terdiri atas fisika, kimia, biologi, dsb.

2) Fenomena (topik yang dibahas), merupakan wujud/benda yang menjadi objek kajian dari disiplin ilmu.

3) Bentuk ialah cara bagaimana suatu subyek dasajikan. Dibedakan menjadi tiga jenis:

a) Bentuk fisik, yakni medium atau sarana yang digunakan dalam menyajikan suatu subyek. Misalnya dalam bentuk buku, majalah, pita rekaman, dan sebagainya.

b) Bentuk penyajian yang menunjukkan pengaturan atau organisasi isi bahan pustaka. Ada tiga bentuk penyajian yaitu ; menggunakan lambang-lambang dalam penyajiannya seperti bahasa, gambar, dll, memperhatikan tata susunan tertentu misalnya abjad, kronologis, dan sebagainya serta menyajikan untuk kelompok tertentu, misalnya bahasa Inggris untuk pemula.

c) Bentuk intelektual yaitu aspek yang menekankan dalam suatu pembahasan subjek. Filsafat Sejarah disini yang menjadi 
subyeknya adalah sejarah sedangkan filsafat adalah bentuk intelektual. $^{11}$

\section{b. Pengindeksan Kata}

Pengindeks mengambil kata/istilah sebagaimana adanya dari judul dokumen, abstrak dokumen atau teks seluruh dokumen. (to derive = mengambil atau memperoleh dari). Juga disebut term indexing. Adapun ciriciri pengindeksan kata ini adalah ; pertama, menggunakan bahasa dokumen, jadi bahasa alami atau kosa kata tak terkendali. Kedua, ada gangguan atau noise akibat sinonim dan homonim. Ketiga, mudah dikerjakan, tidak memerlukan kemampuan intelektual. Keempat, dapat dikerjakan secara mekanis oleh komputer.

Kelebihan pengindeksan kata ini adalah dimana pengindeks tidak perlu mengeskplorasi semua isi dokumen tetapi cukup dengan mengambil kosa kata yang tertera dalam tema dokumen. Kelebihan ini tentu memberikan efek terhadap pengindeks khususnya masalah waktu, tenaga dan fikiran. Dalam banyak kasus, pengindeksan kata yang dilakukan oleh pengindeks dengan melakukan pengindeksan kata seringkali pustakawan hanya mengambil kosa kata yang tidak mewakili dokumen.

\section{Metodologi}

Penelitian ini dilaksanakan di lingkungan Dinas Perpustakaan dan Arsip Kota Jambi. Sedangkan pendekatan metode penelitian yang digunakan pada penelitian ini adalah metode kualitatif. Teknik analisis yang akan digunakan dalam penelitian ini adalah kualitatif, sedangkan pendekatannya adalah deskriptif $^{12}$ Unit populasinya adalah seluruh pustakawan tingkat ahli sebanyak 6 orang, sedangkan untuk penguatan informasi peneliti menggunakan 10 orang

\footnotetext{
${ }^{11}$ Lancaster, F.W. Information Retrieval Systems : Characteristhic, Testing and Evaluating. 2nd ed. (New York: Wiley, 1979). hlm. 17

${ }^{12}$ Pendekatan deskriptif adalah tujuan dari penelitian ini adalah untuk mengungkapkan kejadian atau fakta, keadaan, fenomena, variabel dan keadaan yang terjadi saat penelitian berlangsung dengan menyuguhkan apa yang sebenarnya terjadi. Penelitian ini menafsirkan dan menguraikan data yang bersangkutan dengan situasi yang sedang terjadi, sikap serta pandangan yang terjadi di dalam suatu masyarakat, pertentangan antara dua keadaan atau lebih, hubungan antar variable yang timbul, perbedaan antar fakta yang ada serta pengaruhnya terhadap suatu kondisi, dan sebagainya. (lihat Burhan Mungin, Metodologi Penelitian Kualitatif, Jakarta: Raja. Grafindo. Bogdan, R.C., \& Biklen, S.K 2012).
} 
pemustaka sebagai responden. Karena penelitian ini bersifat kualitatif maka penulis menggunakan sampel purposif. Dalam penelitian ini penulis mengkategorikan informan yang termasuk ke dalam informan kunci adalah Kepala Pembinaan dan Pengembangan Karir Pustakawan selaku pejabat yang menaungi kegiatan profesi kepustakawanan yang diharapkan dapat memberikan izin melakukan penelitian mengenai informasi-informasi yang tidak dapat diobservasi langsung. Selanjutnya adalah para pustakawan yang bertanggung jawab dalam kegiatan pengindeksan, dan para pemustaka yang dapat dimintai keterangannya berkaitan dengan temu balik informasi dokumen yang dilakukan melalui penelusuran katalog subjek dan OPAC. Data dikumpulkan melalui observasi, dokumentasi dan wawancara terstruktur dan tidak terstruktur. Analisis kualitatif dalam penelitian deskriptif dapat dilakukan melalui pengumpulan data, nalisis, reduksi dan kesimpulan. ${ }^{13}$ Sementara untuk keabsahan data dilakukan melalui trianggulasi dan kasus negatif.

\section{E. Sistim Pengindeksan oleh Pustakawan DPAD Kota Jambi dan Dampak pada Sistim Temu Balik Informasi Pemustaka}

\section{Sistim Pengindeksan}

Proses pengindeksan pada sebuah dokumen atau sumber-sumber informasi lain sejatinya dilakukan melalui tiga tahap, dan setiap tahap harus dicermati dengan seksama sehingga tidak menimbulkan pemahaman keliru mengenai indeks yang dihasilkan. Peran pustakawan khususnya pada pustakawan tingkat ahli yang bertanggung jawab dalam kegiatan kepustakwanan ini sangat menentukan pada sistim temu balik informasi yang efektif. Pustakawan atau pengindeks pada tahap proses pengindeksan sejatinya melakukan pencatatan ciri-ciri dokumen yang penting misalnya analisis isi dokumen, klasifikasi dan pembuatan entri-entri katalog. Tujuan pengindeksan ialah memungkinkan ditemukannya dokumen yang relevan dengan suatu permintaan dengan cepat. Salah satu permintaan yang sering dijadikan media penelusuran oleh pemustaka adalah indeks subjek. Kegagalan pemustaka dalam menemukan kembali dokumen lewat indeks subjek

\footnotetext{
${ }^{13}$ Ibid. Bungin. hlm. 90
} 
disebabkan dipengaruhi oleh berapa faktor. Berikut ini adalah hasil deskripsi dari kegiatan pengindeksan di lingkungan Dinas Perpustakaan dan Arsip Daerah Kota Jambi.

\section{a. Memahami Dokumen}

Salah satu elemen yang harus diperhatikan oleh pustakawan dalam proses pengindeksan adalah memahami isi dokumen yang akan diindeks, tidak sekedar hanya memahami tema dokumen akan tetapi harus dianalisis seluruh kandungan dokumen tersebut. Hal ini sangat penting karena mengambil kosa kata dari dokumen yang tidak relevan dengan permintaan akan memungkinkan ketidak tepatan pemustaka dalam browsing informasi. Tujuan dari pengindeksan ini adalah agar kosa kata (istilah) yang digunakan harus searagam untuk bahan perpustakaan mengenai subyek tertentu. Subyek adalah topik yang merupakan kandungan informasi (content) dalam bahan perpustakaan.

Pustakawan di DPAD Kota Jambi umumnya dalam mengindeks dokumen tidak diawali dengan tahapan ini, mereka justru lebih hanya memahami tema dokumen. Temuan penelitian menunjukkan bahwa ada 26 dokumen karya monograf yang diindeks hanya melalui satu istilah, dan 15 diantaranya adalah masih menggunakan bahasa alamiah. Penelusuran dapat dilcak pada katalog subyek dan OPAC. Penulis menilai bahwa ketidak azasan pustakawan dalam melakukan pengindeksan berimbas pada sistim temu balik informasi pemustaka. Pemustaka seringkali tidak menemukan dokumen yang dibutuhkan di rak padahal pada tahap penelusuran sudah menemukan melalui entri katalog (katalog subyek).

Hasil wawancara menunjukkan bahwa 28 pemustaka merasa tidak puas dengan kinerja pustakawan dalam hal pengindeksan. Menurutnya, perlu ada konsistensi pustakawan dalam melakukan pengindeksan agar tidak menimbulkan ketidak puasan di kalangan pemustaka. Penulis menilai bahwa faktor-faktor penyebab ketidak konsistensinya pustakawan dalam hal pengindeksan melalui tahap pemahaman dokumen lebih disebabkan ; pertama, kemampuan pustakawan dalam memahami dokumen seringkali hanya melihat dari sisi temanya saja (pengindeksan kata) tanpa melihat 
substansi dokumen. Model pengindeksan seperti ini seringkali muncul kosa kata yang tidak mewakili dokumen apalagi tema dokumen yang diindeks muncul bahasa alamiah. Kedua, pustakawan tidak menggunakan media tesaurus dan tajuk subjek maupun bagan klasifikasi sebagai media dalam pengindeksan.

\section{b. Analisis Subyek}

Pengindeksan subyek menghasilkan deskripsi indeks (index description) yang merupakan deskripsi ringksa mengenai isi dokumen. Masalah pertama dalam pengindeksan subyek adalah menetapkan subyek yang akan mewakili suatu dokumen. Kesalahan dalam menentapkan subyek akan berdampak pada sistim temu balik informasi. Analisis subyek tidak berarti analisis bidang pengetahuan dalam arti luas. Analisis subyek sebagaimana subyek itu diungkapkan dalam dokumen (library warrant).

Analisis subyek sebagaimana diungkapkan di atas bahwa pengindeks dalam menentukan kosa kata dari suatu dokumen juga harus mampu memahami langkah-langkah dalam menetapkan subyek dokumen, antara lain

\section{1) Disiplin Ilmu atau Fenomena}

Jenis konsep yang pertama-tama harus dikenali oleh pengindeks adalah disiplin ilmu. Istilah ini lebih mengacu pada pemahaman hakikat suatu ilmu pengetahuan ataupun cabang-cabangnya. Pemahaman pada ini lebih dimaksudkan agar pengindeks mampu mana ilmu pengetaahuan dan yang mana bagian dari pembahasan. Hukum, Kimia, Ekonomi misalnya merupakan disiplin ilmu yang merupakan bidang atau cabang ilmu pengetahuan.

\section{2) Bentuk}

Dalam proses pengindeksan subyek, bentuk merupakan salah satu kategori yang harus diperhatikan oleh pengindeks untuk mengetahui bentuk apa dokumen itu, baik sisi fisik, penyajian maupun intelektual. Bentuk fisik misalnya, dalam proses pengindeksan subyek tentang metode penanaman tanaman anggrek yang disajikan dalam buku, compact disk (CD), flash disk. Metode pengindeksan pada tema 
dokumen yang disajikan dalam berbagai media sama sekali tidak mempengaruhi bentuk fisik. Metode pengindeksan tetap isi dokumen yang diperhatikan tentang apa yang dibahas.

Di lingkungan Dinas Perpustakaan dan Arsip Daerah Kota Jambi para pustakawan tetap konsisten terhadap metode pengindeksan ini, artinya pustakawan tidak mempermasalahkan dokumen yang disajikan dalam berbagai media. Ini menunjukkan bahwa pengetahuan pustakawan pada sistim pengindeksan seperti ini tetap konsisten pada standar yang telah ditetapkan. Namun di sisi lain, pustakawan seringkali mengabaikan pengindeksan pada media-media berbentuk compact disk (CD). Penulis banyak menemukan koleksi compact disk (CD) yang berisikan berbagai jenis informasi pengetahuan. Pustakawan hanya lebih memperhatikan pada dokumen tertulis seperti karya monograf.

Pada bentuk penyajian, ada kecendrungan melakukan kesalahan. Misalnya pada saat mengindeks dokumen tentang “ Kamus Kedokteran" pustakawan memilih istilah kamus dan seharusnya pustakawan memilih kedokteran sebagai istilah yang dapat mewaikili dokumen. Begitu juga dokumen tentang “ Statistik untuk pustakawan”, pustakawan atau pengindeks memilih kosa kata perpustakaan, padahal dokumen ini berisikan tentang statistik. Kekeliruan yang dilakukan pustakawan dalam melakukan pengindeksan subyek pada bentuk penyajian berdampak pada sistim temu balik informasi pemustaka. Kekeliruan-kekeliruan yang dilakukan oleh pustakawan sesungguhnya dapat diatasi dengan membuat hubungan hiraki lewat acuan (see atau see also) pada tajuk subjek maupun istilah-istilah yang menunjukkan hubungan antar subyek seperti dalam tesaurus.

\section{c. Penerjemahan}

Kegiatan selanjutnya pasca pemilihan kosa kata dari dokumen adalah menerjemahkan konsep-konsep tersebut ke dalam bahasa indeks (language controled). Dalam tahap ini pengindeks dituntut untuk menerjemahkan konsep-konsep tersebut dengan tepat agar tidak terjadi kekeliruan mengenai konsep yang mewakili dokumen. Barbara M. Wesby 
merekomendasikan bahwa pengindeks dalam menerjemahkan kosa kata yang terpilih harus menggunakan daftar tajuk subjek dan tesaurus.

Di lingkungan Dinas Perpustakaan dan Arsip Daerah Kota Jambi, kebiasaan pustakawan dalam melakukan pengindeksan adalah memilih kosa kata yang lebih merujuk pada kosa kata yang tampak di tema dokumen, itupun terkadang tidak melakukan proses penerjemahan. Beberapa katalog subyek yang telah dibuat oleh pustakawan masih menggunakan bahasa alamiah. Penggunaan bahasa alamiah dalam pengindeksan subyek sesungguhnya bukan tidak dianjurkan karena memiliki kelebihan, namun menimbulkan ketidak taat azasan terhadap semua dokumen yang diindeks.

Latar belakang pendidikan dan pengetahuan pustakawan juga berdampak pada proses pengindeksan subyek pada dokumen. Pusakawan yang dengan latar belakang pendidikan non ilmu perpustakaan seringkali keliru dalam menetapkan subyek yang bisa mewakili dokumen. Hal ini dipengaruhi oleh beberapa faktor, antara lain ; ketidak tahuan dalam menggunakan tajuk subjek maupun tesaurus ; kelamahan dalam menerjemahkan subjek dokumen sehingga seringkali subyek yang terpilih tidak mewakili dokumen; ketidak asazan dalam menetapkan subyek sehingga muncul beberapa subyek yang tidak relevan dengan temu balik informasi ; kurangnya koordinasi antara satu pustakawan dengan pustakawan yang lain dalam proses pengindeksan subyek.

\section{Dampak Sistim Temu Balik Informasi}

Fosket mengemukakan "relevance the likelihood of their matching our readers requirements." Pendapat ini menyatakan relevansi adalah tingkat kesesuaian dari dokumen yang terpanggil dari sistem dengan permintaan pemakai. Penilaian relevansi merupakan tahap pekerjaan yang penuh dengan ketelitian. Hal ini disebabkan karena dalam tahap inilah menentukan apakah dokumen relevan dengan kebutuhan informasi pemakai dan tahap ini juga merupakan tolok ukur untuk mengevaluasi sistem dan proses sistem temu balik

informasi. Penilaian relevansi adalah bersifat individual bagi setiap penilai, 
dalam arti penilai yang berbeda akan menghasilkan penilaian yang berbeda pula.

Penilaian relevansi bertujuan untuk menilai dokumen yang terpanggil dari berbagai dokumen yang terpanggil apakah sesuai dengan keinginan pemakai. Menurut Irma U. Adititrto bahwa kosa kata mempunyai pengaruh secara tidak langsung pada fungsi penindeksan dan penelusuran. Penelusuran sangat berpengaruh oleh struktur kosa kata indeks. Makin terstruktur dan makin banyak hubungan yang diperagakan makin membantu penelusur yang akan menyusun strategi penelusuran. ${ }^{14}$

\section{a. Perolehan}

Pemustaka dalam mengidentifikasi dokumen yang dibutuhkan merupakan impian dalam proses temu balik informasi di perpustakaan. Harapan pemustaka agar informasi yang diperoleh dapat memuaskannya. Berikut ini adalah deskripsi dari 10 pemustaka yang melakukan penelusuran terhadap informasi melalui subjek yang diharapkan.

\begin{tabular}{|c|l|l|c|c|c|}
\hline No & Pemustaka & \multicolumn{1}{|c|}{ Subjek } & $\begin{array}{c}\text { Dokumen } \\
\text { Relevan } \\
\text { yang } \\
\text { Ditemukan }\end{array}$ & $\begin{array}{c}\text { Total } \\
\text { Dokumen } \\
\text { Relevan }\end{array}$ & $\begin{array}{c}\text { Angka } \\
\text { Perolehan } \\
\%\end{array}$ \\
\hline 1. & A & Ekonomi Islam & 6 & 14 & 42,85 \\
\hline 2. & B & Pendidikan Usia Dini & 7 & 18 & 38,9 \\
\hline 3. & C & Perpustakaan digital & 6 & 12 & 50 \\
\hline 4. & D & Hukum Waris & 5 & 10 & 50 \\
\hline 5. & E & Filsafat ilmu & 4 & 12 & 33,33 \\
\hline 6. & F & Komunikasi antar budaya & 3 & 8 & 37,5 \\
\hline 7. & G & Teknologi pangan & 7 & 14 & 50 \\
\hline 8. & H & Metopen Kualitatif & 7 & 12 & 58,33 \\
\hline 9. & I & Kesusastraan Melayu & 2 & 6 & 33,33 \\
\hline 10 & J & Kimia terapan & 5 & 10 & 50 \\
\hline & & Jumlah & 52 & 116 & 44,82 \\
\hline
\end{tabular}

Beradasarkan tabel di atas menunjukkan rata-rata perolehan pemustaka terhadap dokumen yang diharapkan hanya $44,82 \%$ ini menunjukkan bahwa pemilihan konsep subjek pada dokumen seringkali memilih konsep-konsep yang yang tidak mewakili dokumen. F.W Lancaster menilai bahwa kesalahan yang dilakukan oleh pustakawan atau

\footnotetext{
${ }^{14}$ F. W. lancaster, Vocabulary control for information retrieval. (Washington : Information Resources Press, 1972). hlm. 281
} 
penginedeks adalah tidak mengeluarkan konsep yang dapat mewakili deskripsi indeks. Selanjutnya dikatakan bahwa kegagalan dalam perolehan temu balik informasi lebih disebabkan karena ada konsep penting yang tidak terwakili. Kesalahan ini karena kecerobohan dan kelalaian pengindeks bukan kelemahan pada kosa kata. Namun demikian adakalanya juga disebabakan oleh kosa kata entri yang kurang memadai. ${ }^{15}$ Pustakawan atau pengindeks tidak tahu bagaimana suatu subyek harus dinyatakan tidak ada deskriptor yang cocok dalam kosa kata indeks, dan kosa kata entri tidak mengarahkan pengindeks.

Dengan demikian bahwa perolehan dokumen yang dilakukan oleh pemustaka Dinas Perpustakan dan Arsip Daerah Kota Jambi menunjukkan kurang relevan dengan harapan yang diinginkan. Faktor- faktor yang menyebabkan rendahnya perolehan dari penelusuran pemustaka terhadap dokumen yang diharapkan antara lain; pertama, metode penelusuran pemustaka yang konvensional artinya pemustaka hanya menggunakan satu konsep dan tidak menggunakan penggabungan. Kedua, konsep subyek yang diindeks oleh pengindeks seringkali tidak relevan dengan dokumen begitu juga dengan penggunaan istilah sinonim maupun homonim menyebabkan pemustaka bingung. Ketiga, tidak ada media bantu penelusuran semisal daftar tajuk subjek maupun tesaurus. Penyebab tidak adanya media tesaurus dan daftar tajuk subjek di perpustakaan lebih disebabkan karena seringkali diabaikan oleh pustakawan dalam proses pengindeksan. Pustakawan menganggap bahwa dengan menggunakan media seringkali dianggap terlalu sukar akibatnya pustakawan lebih memilih mengindeks dokumen tanpa rujukan.

\section{b. Ketepatan}

Ratio ketepatan yang baik (tinggi) menandai bahwa dari pihak pemakai tidak dituntut upaya besar untuk memilah-milah lagi dokumendokumen yang terjaring untuk mendapatkan yang sungguh-sungguh relevan. Kemampuan pemustaka dalam memperoleh dokumen yang tepat

\footnotetext{
${ }^{15}$ Ibid. F. W. lancaster, Vocabulary control..... hlm. 286
} 
juga didasarkan pada kemampuan pemustaka dalam melakukan penelusuran dengan mengidentifikasi subyek yang diinginkan melalui metode penelusuran yang tepat. Berikut ini adalah jumlah dokumen yang tepat melalui penelusuran beberapa subyek.

\begin{tabular}{|c|c|l|c|c|c|}
\hline No & Pemustaka & \multicolumn{1}{|c|}{ Subjek } & Dokumen & Ketepatan & \% \\
\hline 1. & A & Koperasi & 42 & 6 & 14,28 \\
\hline 2. & B & $\begin{array}{l}\text { Sistim Perpolitikan Pasca } \\
\text { Reformasi di Indonesia }\end{array}$ & 20 & 2 & 10 \\
\hline 3. & C & $\begin{array}{l}\text { Kurikulum Pendidikan } \\
\text { Tinggi }\end{array}$ & 27 & 5 & 18,51 \\
\hline 4. & D & $\begin{array}{l}\text { Sumber daya Manusia } \\
\text { Perguruan Tinggi }\end{array}$ & 28 & 4 & 14,28 \\
\hline 5. & E & Literasi Informasi & 15 & 2 & 13,3 \\
\hline 6. & F & Psikologi Komunikasi & 36 & 6 & 16,6 \\
\hline 7. & G & $\begin{array}{l}\text { Teknologi Informasi } \\
\text { Digital }\end{array}$ & 51 & 7 & 13,72 \\
\hline 8. & H & Filsafat Agama & 41 & 7 & 17,07 \\
\hline 9. & I & Linguistik Terapan & 19 & 21,05 \\
\hline 10 & J Adat dan Budaya Melayu & 18 & 11,11 \\
\hline & Jambi & 297 & 45 & 15,15 \\
\hline
\end{tabular}

Berdasarkan tabel di atas menunjukkan bahwa rata-rata ketepatan dalam penelusuran dokumen oleh pemustaka di Dinas Perpustakaan dan Arsip Daerah Kota Jambi sangat rendah yakni hanya 15,15\%. Ini menunjukkan bahwa masih ada beberapa hal yang perlu diperbaiki oleh pengindeks atau pustakawan dalam memperbaiki kinerjanya terkait dengan pengindeksan subjek pada dokumen monograf. Pemustaka dalam melakukan penelusuran terjaring sejumlah dokumen-dokumen yang tidak diharapkan. Kurangnya spesifik kosa kata yang digunakan oleh pengindeks ditengarai sebagai efek dari rendahnya ketepatan sistim temu balik informasi. Kosa kata yang spesifik dengan sendirinya akan membatasi tingkat ketepatan sistim tersebut. Tema-tema dokumen yang dijadikan sebagai sampel diatas umumnya diindeks oleh pustakawan dengan kosa kata umum. Misalnya pada kosa kata teknologi, pada saat penelusuran menemukan 51 dokumen sebab beberapa dokumen membahas tentang teknologi sementara pemustaka mengharapkan kosa kata khusus misalnya teknologi informasi digital. 
Kegagalan dalam proses temubalik informasi pada saat penelusuran informasi terkadang bukan semata kelemahan pemustaka dalam menggunakan berbagai metode penelusuran informasi juga disebabkan karena tidak munculnya kosa kata yang dipakai pemustaka. Ketidak munculnya kosa kata tersebut menurut Irma U. Aditirto bahwa dalam proses pengindeksan lebih disebabkan karena ;

1. Kegagalan dalam analisis konseptual - pengindeks gagal memahami pokok bahasan dokumen dan melakukan interpretasi salah terhadap isi dokumen

2. Kegagalan dalam penerjemahan - pengindeks mengenali subyek dokumen, namun memilih istilah yang salah untuk mewakilinya.

3. Konsep yang tidak terwakili - terjadi apabila pengindeks dalam analisis konseptualnya karena satu dan lain sebab tidak memilih / mengeluarkan konsep tertentu

4. Kosa kata kurang spesifik - pengindeks mengenali subyek dokumen dan dalam analisis konseptualnya mengeluarkan subyek spesifik tersebut, namun terpaksa mengindeksnya dengan menggunakan istilah yang lebih umum karena tidak ada istilah yang lebih spesifik dalam kosa kata indeks

5. Kekhususan yang terlampau rendah - pengindeks menggunakan istilah indeks yang terlampau umum untuk suatu subyek, meskipun dalam kosa kata ada istilah yang lebih spesifik. ${ }^{16}$

\section{F. Kesimpulan`}

Berdasarkan deskripsi di atas menunjukkan bahwa sistim pengindeksan yang tidak dilakukan secara profesional berdampak pada ketepatan dokumen yang diinginkan oleh pemustaka pada tahap penelusuran informasi dokumen di perpustakaan. Pustakawan lebih cendrung melakukan pengindeksan tanpa menggunakan media-media seperti tesaurus dan daftar tajuk subjek, mereka hanya mengandalkan bagan klasifikasi. Disisi lain bahwa pustakawan cendrung melakukan pengindeksan secara individual tidak berkolaborasi dengan sesama pustakawan sehingga seringkali muncul persepsi yang berbeda pada tahap melakukan pengindeksan khususnya pada tahap penerjemahan konsep.

\footnotetext{
${ }^{16}$ Irma U. Aditirto. Pengindeksan Subyek. Bahan Mata kuliah Kosa Kata Indeks, S1 Khusus Progam Studi Ilmu Perpustakaan Fakultas Sastra Universitas Indonesia. (Jakarta : FS-UI, 1999), hlm. 4
} 


\section{DAFTAR PUSTAKA}

Anonim. Kamus Besar Bahasa Indonesia, (Jakarta: P dan K, 1994)

F.W. Lancaster. Vocabulary Control for Information Retrieval, $2^{\text {nd }}$ ed.

Hasugian, Jonner. Dasar-Dasar Ilmu Perpustakaan dan Informasi. (Medan: USU Press, 2003)

Irma U. Aditirto. Kebijaksanaan Pengindeksan. Bahan Mata Kuliah Kosa Kata Indeks, Jurusan Ilmu Perpustakaan Fakultas Sastra Universitas Indonesia, 1997)

Irma U. Aditirto. Pengindeksan Subyek. Bahan Mata kuliah Kosa Kata Indeks, S1 Khusus Progam Studi Ilmu Perpustakaan Fakultas Sastra Universitas Indonesia. (Jakarta: FS-UI, 1999)

Kowalski, Gerald J. Information Retrieval Systems : Theory and Implementation. (USA: Springer, 2007).

Lancaster, F.W. Information Retrieval Systems : Characteristhic, Testing and Evaluating. 2nd ed. New York: Wiley, 1979)

Lasa HS. Jenis-Jenis Layanan Informasi Perpustakaan : sirkulasi dan Referensi. (Jakarta: Universitas: Gajahmada Press, 2006)

Robert R. Korfhage 1997: Publication of Korfhage's Information Storage and Retrieval $^{[25]}$ with emphasis on visualization and multi-reference point systems. (England: Cranfield Collection of Aeronautics, Cranfield, 1997)

Wojtczak, A., 2002, Glossary of Medical Education Terms, http://www.iime.org/glossary.htm, December, 2000, Revised February 2002, accessed 2 September 2012

Zulfikar Zen, 2013. Pengantar Ilmu Perpustakaan. Makalah disampaikan pada Diklat: Manajemen Perpustakaan yang diselenggarakan oleh BADAN LITBANG DAN DIKLATDEPARTEMEN AGAMA RIJakarta, 10 - 16 April 2008.

Andrei Z. Broder dkk. Identifying and filtering near-duplicate documents. In CPM '00,pages 1-10, 2000

Edward Evans, Margaret Zarnosky Saponaro. Developing Library and Information Center Collections (Library Science Text Series) 3rd Edition, (Amazone: Libraries Unlimited, 1995) 